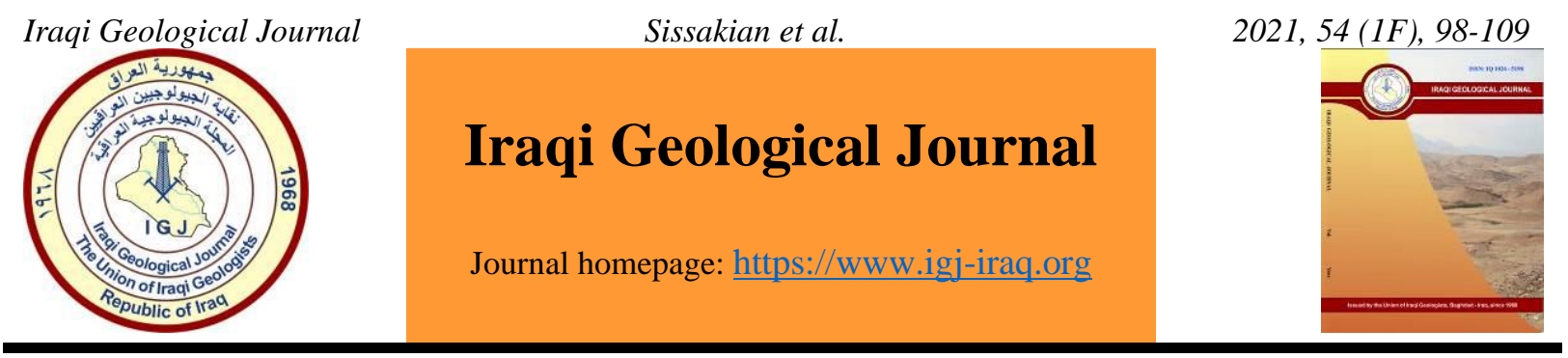

\title{
Slope Stability Analysis of Haibat Sultan Road Cut, Kurdistan Region, Iraq Using a Field Method
}

\author{
Varoujan K. Sissakian ${ }^{1 *}$, Hamed M. Jassim², Mark J. Vanarelli ${ }^{3}$ and Hassan O. Omer ${ }^{4}$ \\ ${ }^{1}$ Department of Natural Resources Engineering and Management, School of Science and Engineering, University of \\ Kurdistan Hewler, Erbil, Iraq \\ ${ }^{2}$ Department of Petroleum and Mining Engineering, Faculty of Engineering and Science, Tishk International University, \\ Erbil, Iraq \\ ${ }^{3}$ COVAN Engineering LLC, Westminster, Colorado, USA \\ ${ }^{4}$ Department of Natural Resources Engineering and Management, School of Science and Engineering, University of \\ Kurdistan Hewler, Erbil, Iraq \\ *Correspondence: varoujan49@yahoo.com.
}

Received: 26 February 2021; Accepted: 8 April 2021; Published: 30 June 2021

\begin{abstract}
The road that crosses the Haibat Sultan Mountain in the northern part of Iraq; is one of the dangerous roads in this region. To perform a slope stability analysis for the dangerous parts of the road, we have used Bejerman's Method. We have reviewed satellite images of the road and all those potential areas were checked in the field; accordingly, eleven stations were recognized. Landslide Possibility Index was determined at the studied stations following Bejerman's field method. The road climbs the southern face (dip slope) of the mountain through very hard carbonate rocks of the Pila Spi Formation, where the bedding planes daylight in the slope face near the road cuts. This produced many large landslides. Along the northern face of the mountain, the road runs through soft clastic rocks where joint planes in the rock mass intersect and daylight in the slope face near the road cut. In order to prevent future wedge failures, a $30 \mathrm{~m}$ offset was created from the toe of the slope to the road. In almost all cases, the Landslide Possibility Index indicated a moderate to very high likelihood for failure along all road cuts.
\end{abstract}

Keywords: Bejerman Method; Slope failure; Landslide; Landslide Possibility Index; Northern Iraq

\section{Introduction}

The roads in the northern part of Iraq are mainly mountainous with high ascending and descending steep mountain slopes where haphazard road cuts have created instability problems and/or potential areas for sliding. Among those roads is the road that crosses Haibat Sultan Mountain, north of Koya town, central northern part of Iraq that exhibits many examples of slope instability cases. For example, in one occasion in 2013, major slides took place and the road was closed for about three months to do repairs. However, no causalities were recorded. This is mainly due to haphazard road construction without scientific consideration of the type of the rocks, their hardness and thicknesses, and the orientation of bedding, joints, fractures and faults, which all have an impact on the rock strength and stability of the slopes. The main problem that the current research work dealt with is the unstable slopes which exist along the studied part of Haibat Sultan Mountain road. Besides, the reasons of the unstable DOI: 10.46717/igj.54.1F.9ms-2021-06-29 
slopes, their effect on the traffic, safety of users of the road, and the safety of the community living near by the road.

Many methods are available to assess the stability of slopes along road cuts, amongst which are the following: The Kinematic Analysis Method using Dip Analyst 2.0 (Admassu, 2014); Markland (1972) Hocking (1976), Hoek and Bray (1981), Bejerman (1994) Watts et al. (2003). Bejerman (1994) method was the one which was adopted in this study. However, Bejerman's Method is used in the current research work because: 1) It is a field method, 2) No need for specialists to conduct the analysis of the unstable slopes, 3) No need for special equipment and laboratories, and 4) It is very quick and cheap method, as compared to other aforementioned methods. The study area is located near Koya town (Fig. 1) within the central northern part of Iraq; $73 \mathrm{~km}$ southeast of Erbil. The studied part of the road climbs Haibat Sultan Mountain as a very steep single lane road with bedding planes daylighting in the slopes next to the road.

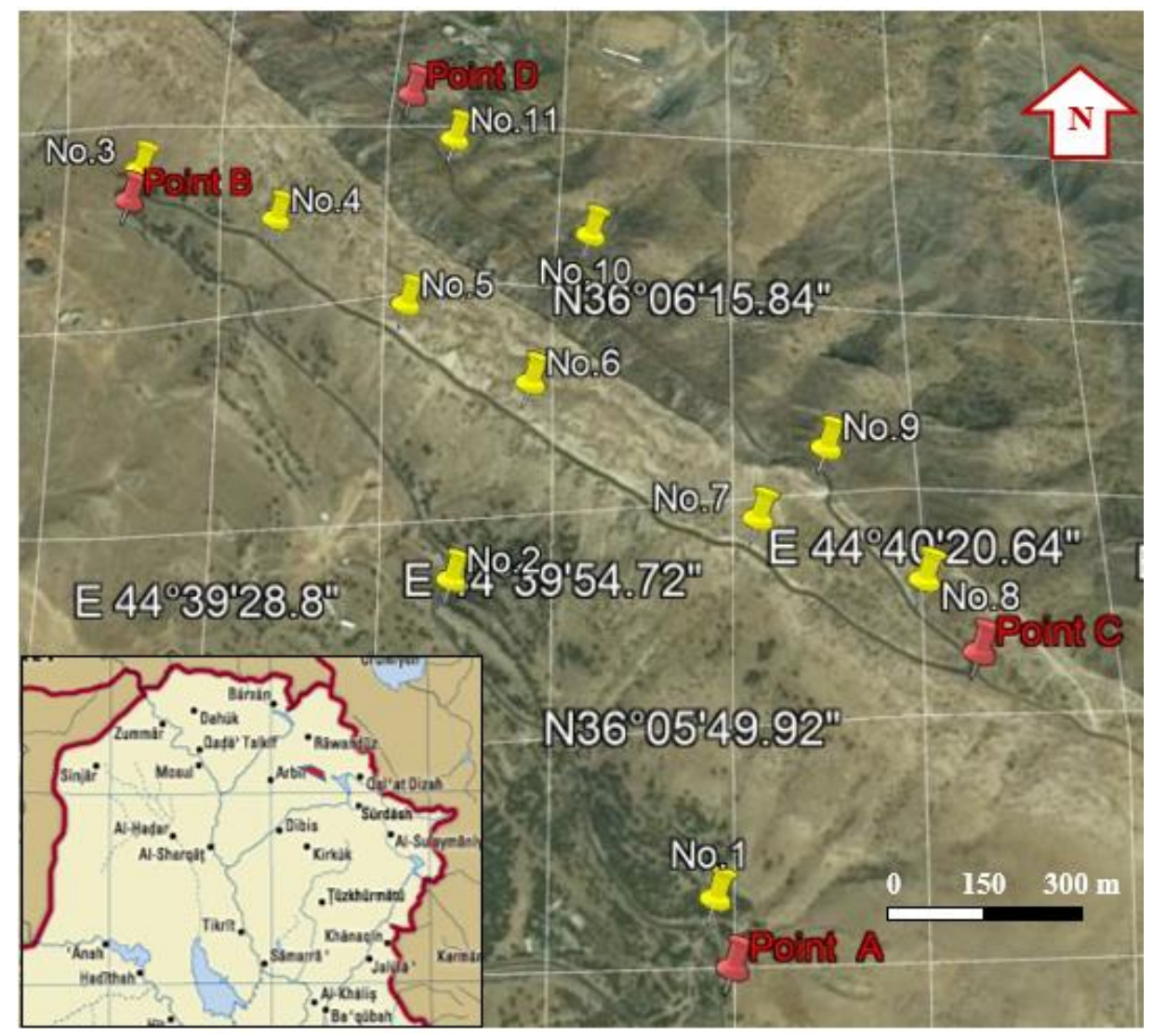

Fig. 1. Satellite image of the studied part of Haibat Sultan crossing road showing the studied stations with serial numbers, and three sections (parts) of the road. The red rectangle shows the location of the studied road at Iraq

Studies that dealt with slope instability problems in the northern part of Iraq are very rare although hundreds of slope failures occur almost everywhere in the region. However, many studies and maps are presented by different authors but the majority of them are regional and don't identify neither the cause nor types of failure. Some of these maps and studies are presented hereinafter: Hamasour (1991) studied the unstable parts of the road and evaluated the types of mass movements using Bejerman's Method. Sissakian et al. (2011), studied the geological hazards in Iraq, and presented maps of different scales, they referred to the study area as one of the most hazardous areas with unstable slopes. Al-Saadi and Yousif (2013) evaluated a road cut slopes west of the study area using Bejerman's Method. Jassim et al. (2013 and 2014) studied the instability of the road through 14 studied stations and concluded that the possibility of sliding is high, with the landslides and rock falls being the main types of mass 
movements. Sidiq et al. (2015) studied a large landslide that had occurred on 11//11/ 2015 along the concerned road. They documented the details and causes of the landslide, and gave recommendations for stabilizing the road cuts. Yousif and Shakir (2015) also have used Bejerman's Method to evaluate rock falls along a main road in northern part of Iraq. Sissakian et al. (2018), evaluated unstable road cut west of the current study area using Bejerman's method. Mohammed et al. (2020), used Bejerman's Method to evaluate the landslide possibility along a mountainous road in the NE of Iraq.

The aim of this research work is to perform slope stability analysis of the unstable slopes along the studied part of Haibat Sultan Mountain crossing road using qualitative field method which was developed by Bejerman (1994). This method has been used in previous investigations (Bejerman, 1994 and 1998; Sissakian et al., 2018 and 2020; Al-Saadi and Yousif, 2013). The method was used to evaluate unstable slopes, whereby some remedial measures to stabilize them were recommended.

\section{Materials and Methods}

Satellite images, geological and topographical maps of different scales, and relevant published articles and reports were studied to perform this research work.

\subsection{Field Investigation}

On 9th of October, 2017, a field investigation was performed to the studied part of the road to identify the potential unstable parts of the slopes and to collect the necessary field data to perform the slope stability analysis using Bejerman's Method (1994). The Landslide Possibility Index (L.P.I.) was calculated as proposed by Bejerman (1994) at eleven recognized stations where unstable slopes and/ or potential areas that are likely to become unstable in the near future were recognized. The Landslide Possibility Index (L.P.I.) assesses landslide possibility for rock slopes along mountainous roads as well as in natural slopes (Bejerman, 1994). The L.P.I. identifies ten characteristics and or parameters for evaluating the possibility of the re-occurrence of mass movements in an area of concern.

\subsection{Field Description of the Studied Stations}

The eleven stations along the road cut represent those areas where slope failures have occurred and/or are prone to failure. At each station, a detailed description is given including the type of recent and/or very old slope failures that have occurred and other relevant observations (Table 1).

\subsection{Description of the Road}

The studied part of the road, which crosses Haibat Sultan Mountain, is divided into three sections (parts) (Fig. 1 and Table 2). The elevations (above sea level, a.s.1.), distances, gradients of the three sections and the number of the studied stations are assigned in Table 2. The road climbs the southern face of the mountain through the well bedded and hard rocks of the Pila Spi Formation. Almost all the road cuts in the first sector are characterized by bedding planes which daylight in the slope face; seasonally many failures occur, some of which have blocked traffic. The main mass movement types are sliding and toppling. The road along the northern face of the mountain runs through soft clastic rocks of the Gercus and Kolosh formations. Although the dip of the beds is opposite to the slope; still some small unstable slopes do exist along the road. The main types of mass movements are rock fall, toppling and wedge sliding. The three sections of the road are described hereinafter.

Section A - B: This section runs within the Fatha Formation; therefore, the road cuts are mainly within soft classics. Number of the studied stations is 2 (Nos. 1 and 2). 
Table 1. Brief field description of the eleven studied stations

\begin{tabular}{|c|c|c|c|}
\hline $\begin{array}{l}\text { station } \\
\text { No. }\end{array}$ & $\begin{array}{c}\text { Road } \\
\text { Section }\end{array}$ & $\begin{array}{l}\text { Mass } \\
\text { Movement }\end{array}$ & Field Observations \\
\hline 1 & \multirow{4}{*}{$\begin{array}{l}\text { Part } \\
\mathrm{A}-\mathrm{B}\end{array}$} & Soil Slump & Recent soil failure indication with successive scarps $(30-50 \mathrm{~cm})$ \\
\hline 2 & & Soil Creep & $\begin{array}{l}\text { Old soil creep within slope sediments of coarse rock fragments; indicated } \\
\text { by bended trees. }\end{array}$ \\
\hline 3 & & Soil Creep & $\begin{array}{l}\text { Old soil creep within slope sediments of coarse rock fragments covering } \\
\text { the bed rock; indicated by bended trees (Fig. 5) }\end{array}$ \\
\hline 4 & & Landslide & $\begin{array}{l}\text { Daylighting bedding planes within rocks of the Pila Spi Formation with } \\
\text { indication of recent failure (Fig. 4). }\end{array}$ \\
\hline 5 & \multirow[t]{3}{*}{$\begin{array}{l}\text { Part } \\
\mathrm{B}-\mathrm{C}\end{array}$} & Landslide & $\begin{array}{l}\text { Daylighting bedding planes within rocks of the Pila Spi Formation with } \\
\text { indication of recent failure and a claystone beds with slicken side (Figure }\end{array}$ \\
\hline 6 & & Soil Slump & $\begin{array}{l}\text { Recent soil slump within slope sediments of coarse rock fragments } \\
\text { covering the bed rock; large fallen blocks }(1 \times 1 \times 1 \mathrm{~m}) \text { of limestone. }\end{array}$ \\
\hline 7 & & Landslide & $\begin{array}{l}\text { Daylighting bedding planes within rocks of the Pila Spi Formation with } \\
\text { indication of recent failure. Large caverns, which act as water passage }\end{array}$ \\
\hline 8 & \multirow{4}{*}{$\begin{array}{l}\text { Part } \\
\mathrm{C}-\mathrm{D}\end{array}$} & $\begin{array}{l}\text { Rock fall and } \\
\text { toppling }\end{array}$ & Recent and active fall of thinly bedded claystone, as seen along the slope. \\
\hline 9 & & $\begin{array}{l}\text { Rock fall, } \\
\text { toppling and }\end{array}$ & $\begin{array}{l}\text { Recent and active fall of thinly bedded claystone, as seen along the slope. } \\
\text { Two medium sized wedge sliding had occurred. On top of the slope large }\end{array}$ \\
\hline 10 & & $\begin{array}{l}\text { Rock fall and } \\
\text { toppling }\end{array}$ & $\begin{array}{l}\text { Recent and active fall of thinly bedded claystone. Large recently fallen } \\
\text { masses are removed out of the slope (Fig. 7). }\end{array}$ \\
\hline 11 & & $\begin{array}{l}\text { Rock fall and } \\
\text { toppling }\end{array}$ & Recent and active fall of thinly bedded claystone, as seen along the slope. \\
\hline
\end{tabular}

Table 2. Distances and gradients of the three main sections of the road

\begin{tabular}{cccccc}
\hline Point & $\begin{array}{c}\text { Elevation } \\
(\mathbf{m})(\mathbf{a} . \mathbf{s} . \mathbf{l} .)\end{array}$ & $\begin{array}{c}\text { Section } \\
(\text { Part })\end{array}$ & $\begin{array}{c}\text { Distance } \\
(\mathbf{k m})\end{array}$ & Gradient & Number of studied stations \\
\hline A & 683 & A - B & 1.997 & $1: 0.062$ & 2 \\
B & 807 & B - C & 1.864 & $1: 0.062$ & 5 \\
C & 923 & C - D & 1.691 & $1: 0.051$ & 4 \\
D & 837 & & & & \\
\hline
\end{tabular}

Section B - C: This section runs within the Pila Spi Formation. This part is the most dangerous and includes the main landslides. Number of the studied stations is 5 (No. 3, 4, 5,6 and 7).

Section C - D: This section runs also within the Pila Spi Formation then runs within the Gercus and Kolosh formations. Number of the studied stations is 4 (No. 8, 9, 10 and 11).

\section{Geological Setting}

The geological setting concerning the studied area is briefly mentioned including stratigraphy, geomorphology, and tectonics and structural geology.

\subsection{Stratigraphy}

The exposed rocks within different geological formations at the studied area are briefly mentioned (Sissakian and Al-Jiburi, 2014). A geological map is presented in Fig. (2). The geological formations are described from the oldest to the youngest; hereinafter. 


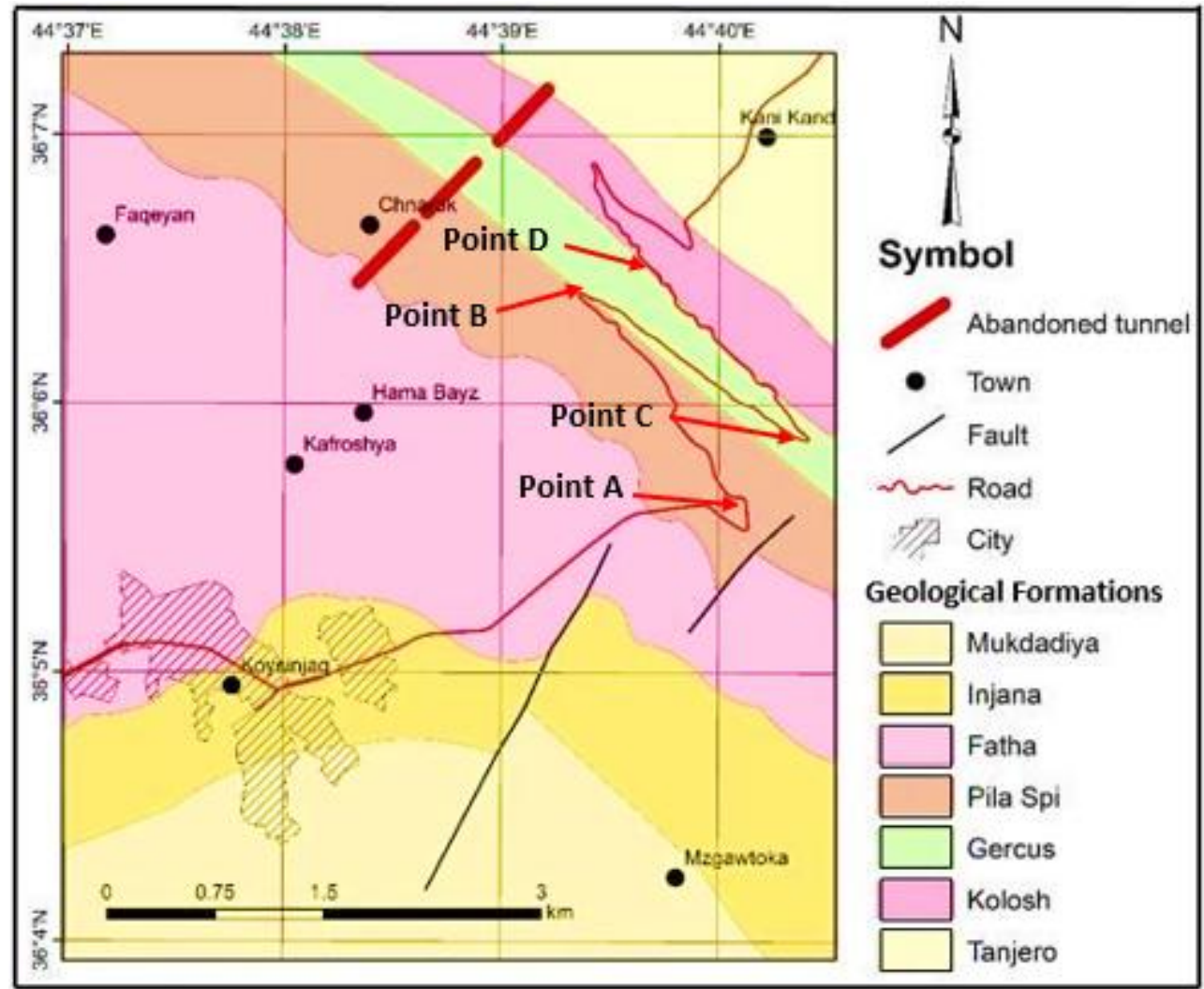

Fig. 2. Geological Map of the study area (After Sissakian and Fouad, 2015)

Kolosh Formation (Paleocene): The formation consists of black fine clastic, with some limestone tongues (Khurmala Formation). The exposed thickness is about $85 \mathrm{~m}$.

Gercus Formation (Eocene): The formation consists of reddish brown thinly well bedded, soft, intensely jointed clastic. The thickness is about $120 \mathrm{~m}$

Pila Spi Formation (Upper Eocene): The formation consists of white to greyish white, well bedded, hard to very hard limestone and dolostone with some yellowish white marly limestone. The thickness is about $100 \mathrm{~m}$.

Fatha Formation (Middle Miocene): The formation consists of cyclic sediments. Each cycle consists of alternation of thick reddish brown and soft claystone, bedded, white, hard limestone and grey gypsum. The thickness is about $220 \mathrm{~m}$.

Injana Formation (Upper Miocene): The formation consists of cyclic sediments, each cycle consists of alternation of hard sandstone, siltstone and soft claystone; reddish brown in color. The thickness is about $320 \mathrm{~m}$.

\subsection{Geomorphology}

The main geomorphological features and phenomena are mass movements of different types, and the outstanding long anticlinal steep and high ridges that form the bulk of Haibat Sultan Mountain. The ridges are characterized by giant flatirons with heights ranging between $25-150 \mathrm{~m}$. The southwestern slope of the ridge is the manifestation of the dip of the bedding planes of thickly, well bedded to massive, and hard limestone beds which exhibit different types of mass movements with different sizes which form the most dangerous part of the road. 


\subsection{Tectonics and Structural Geology}

The contact between the Low Folded Zone and the High Folded Zone is represented by the main ridge in the studied area. The two zones are formed due to the collision of the Arabian and Eurasian plates and they are part of the Outer Platform of the Arabian Plate. They are also part of the Zagros Thrust - Fold Belt (Fouad, 2015). The ridge along which the road climbers the Haibat Sultan Mountain is the southwestern limb of Bustana anticline and continues southeastwards to form the south western limb of a very wide anticline called Khalikan anticline. The ridge trends NW - SE (Fig. 2) with very steep slope. The dip amount ranges between $33-71^{\circ} \mathrm{SW}$. The existing faults (Fig. 2) haven't any significant role in the stability of the studied slopes. However, the intense jointing (two main sets) which are perpendicular to the bedding planes and to each other have significant role in the stability of the slopes, and in their failure, as the bedding slide is the most common feature in the studied area.

\section{Results}

The following results have been acquired from field investigation and application of Bejerman's (1994) Method.

\subsection{Field Analysis of Landslide Possibility Index (L.P.I.)}

To check the stability of the studied area, the method developed by Bejerman (1994) was applied in eleven selected studied stations (Fig. 1) depending on the L.P.I. classification given by Bejerman (1994 and 1998) (Table 3). By applying the total scored L.P.I. marks (Table 4) at each of the eleven studied stations, the grade, category of L.P.I., failure possibility and hazard zone at each studied station were determined. The results are presented in Table 5.

Table 3. Landslides hazard categories (After Bejerman, 1994 and 1998)

\begin{tabular}{cccccc}
\hline \multicolumn{2}{c}{ Landslide Possibility Index (L.P.I.) } & $\begin{array}{c}\text { Failure } \\
\text { Possibility }\end{array}$ & $\begin{array}{c}\text { L. P. I. } \\
\text { value }\end{array}$ & $\begin{array}{c}\text { Hazard } \\
\text { Zone }\end{array}$ \\
\hline Grade & Category & Estimation & & & \\
VI & Very High & $>25$ & High & $>25$ & High Hazard \\
V & High & $21-25$ & Moderate & & \\
IV & Moderate & $16-20$ & Low & $(11-24)$ & Moderate Hazard \\
III & Low & $11-15$ & Very Low & $<10$ & Low Hazard \\
II & Very Low & $6-10$ & Small & & \\
\hline
\end{tabular}

The L.P.I. values for each of the eleven studied stations were calculated in the field based on ten given aspects (Table 4, aspects No. 1-10) by Bejerman (1994). The ten aspects were measured and/ or estimated as follows: The slope height (No. 1) by measuring tape, slope angle (No. 2) by Brinton compass, grade of fracture (No. 3) and of weathering (No. 4) by direct inspection of the outcrops based on Hack and Price (1997), gradient of discontinuity (No. 5) by Brinton compass, spacing of discontinuity (No. 6) by measuring tape; both last 2 aspects were documented based on Hoek and Bray (1981) and Bieniawski (1989), orientation of discontinuity (No. 7) by comparing the direction of the discontinuity with the road cut direction; vegetation cover (No. 8), water infiltration (No. 9), and previous landslides (No. 10) by direct inspection of the concerned areas based on Hangr et al. (2003).

The scored L.P. I. values (Table 4) were compared with the failure possibility classification (Bejerman, 1994 and 1998), which consists of six classes (Table 3). Accordingly, the Grade, Category, Hazard Zone and Failure Possibility were indicated at each studied station and presented in Table (5), which shows that some studied stations indicate Very High Failure Possibility; like stations Nos. 2, 6 and 7 (Table 5). It is worth mentioning that on $30^{\text {th }}$ April 2019 a large landslide occurred after a heavy 
rain storm near studied station No. 7 where L.P.I. value of 28 was determined indicating Grade: VI, Category: Very High, Hazard Zone: High and Failure Possibility: Very High. On 11 November 2015, a large landslide (Fig. 3) had occurred at the same area, which is an excellent indication that the area is a potential area for slope failure and that the used Bejerman's method gives accurate data about the stability of the slopes on road cuts.

Table 4. Raw field data and ratings of L.P.I. of the 11 studied stations (After Bejerman, 1994)

\begin{tabular}{|c|c|c|c|c|c|c|c|c|c|c|c|}
\hline \multirow{4}{*}{ 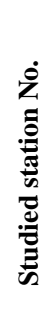 } & \multicolumn{11}{|c|}{ Numbers of the aspects used in L.P.I. Form } \\
\hline & \multirow{2}{*}{\multicolumn{2}{|c|}{$\begin{array}{l}\text { Slope } \\
\text { Slo }\end{array}$}} & \multirow{2}{*}{\multicolumn{2}{|c|}{$\begin{array}{l}3 \\
\text { Grade of }\end{array}$}} & \multirow[t]{2}{*}{5} & \multirow{2}{*}{\multicolumn{2}{|c|}{$\begin{array}{c}6 \\
\text { iscontinuities }\end{array}$}} & \multirow{3}{*}{$\begin{array}{c}8 \\
\\
\text { Veget- } \\
\text { tion } \\
\text { cover } \\
(\%)\end{array}$} & \multirow{3}{*}{$\begin{array}{c}9 \\
\\
\text { Water } \\
\text { Infil- } \\
\text { tration } \\
(\%)\end{array}$} & \multirow[t]{2}{*}{10} & \multirow{3}{*}{ 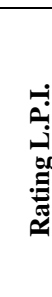 } \\
\hline & & & & & & & & & & & \\
\hline & 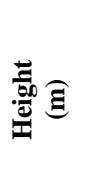 & 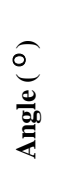 & 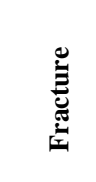 & 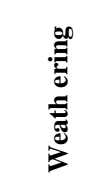 & 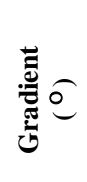 & 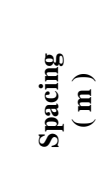 & & & & $\begin{array}{l}\text { Previous } \\
\text { land } \\
\text { slide } \\
\text { volume }\end{array}$ & \\
\hline \multirow{2}{*}{1} & 5 & 40 & Comp & Soil & 13 & $<0.05$ & Unfa. & Abund. & Season. & Not & \multirow{3}{*}{24} \\
\hline & 1 & 2 & 3 & 5 & 0 & 4 & 4 & 2 & 3 & 0 & \\
\hline \multirow{2}{*}{2} & 35 & 45 & Comp. & Soil & 40 & $<0.05$ & Unfa. & Scarce & Season. & Not & \\
\hline & 4 & 2 & 3 & 5 & 2 & 4 & 4 & 1 & 3 & 0 & \multirow[t]{2}{*}{28} \\
\hline \multirow{3}{*}{3} & 8 & 25 & Comp. & Soil & 65 & $0.3-1$ & Unfa. & Abund. & Season. & Not & \\
\hline & 1 & 1 & 3 & 5 & 4 & 2 & 4 & 2 & 3 & 0 & \multirow[t]{2}{*}{25} \\
\hline & 35 & 75 & High & Moder & 75 & $0.3-1$ & Unfa. & Void & Perman & Small & \\
\hline 4 & 4 & 4 & 2 & 2 & 4 & 2 & 4 & 0 & 2 & 1 & 25 \\
\hline \multirow{2}{*}{5} & 24 & 38 & High & Moder & 44 & $1-3$ & Unfa. & Void & Perman & Small & \multirow{3}{*}{19} \\
\hline & 3 & 2 & 2 & 2 & 2 & 1 & 4 & 0 & 2 & 1 & \\
\hline \multirow{2}{*}{6} & 35 & 55 & High & Moder & 35 & $0.3-1$ & Unfa. & Scarce & Season & High & \\
\hline & 4 & 3 & 2 & 2 & 3 & 2 & 4 & 1 & 3 & 2 & \multirow[t]{2}{*}{26} \\
\hline \multirow{2}{*}{7} & 20 & 61 & Comp. & Soil & 35 & $0.3-1$ & Unfa. & Void & Season & Small & \\
\hline & 3 & 4 & 3 & 5 & 3 & 2 & 4 & 0 & 3 & 1 & \multirow[t]{2}{*}{28} \\
\hline \multirow{2}{*}{8} & 12 & 60 & High & High & 49 & $0.05-0.3$ & Favo. & Void & Scarce & Small & \\
\hline & 2 & 3 & 2 & 3 & 3 & 3 & 0 & 0 & 1 & 1 & \multirow[t]{2}{*}{12} \\
\hline \multirow{2}{*}{9} & 56 & 68 & High & High & 51 & $0.05-0.3$ & Favo. & Scaece & Scarce & Small & \\
\hline & 5 & 4 & 2 & 3 & 3 & 3 & 0 & 1 & 1 & 1 & \multirow[t]{2}{*}{17} \\
\hline \multirow{2}{*}{10} & 75 & 60 & High & High & 42 & $0.05-0.3$ & Favo. & Scarce & Scarce & Small & \\
\hline & 5 & 3 & 2 & 3 & 2 & 3 & 0 & 1 & 1 & 1 & \multirow[t]{2}{*}{17} \\
\hline \multirow{2}{*}{11} & 25 & 80 & High & High & 60 & $0.05-0.3$ & Favo. & Scarce & Scarce & Small & \\
\hline & 3 & 4 & 2 & 3 & 3 & 3 & 0 & 1 & 1 & 1 & 15 \\
\hline
\end{tabular}

Comp. $=$ Completely, Moder $=$ Moderately, Favo. $=$ Favorable, Unfa. $=$ Unfavorable, Abund =Abundant, Season. $=$ Seasonal.

Table 5. L.P.I. scored marks and Grade, Category, Hazard Zones, and Failure Possibility (After Bejerman, 1994) at the 11 studied stations

\begin{tabular}{lccccc}
\hline $\begin{array}{l}\text { Station } \\
\text { No. }\end{array}$ & $\begin{array}{c}\text { L.P.I. } \\
\text { Value }\end{array}$ & \multicolumn{2}{c}{ LPI } & $\begin{array}{c}\text { Hazard } \\
\text { Zone }\end{array}$ & $\begin{array}{c}\text { Failure } \\
\text { Possibility }\end{array}$ \\
\hline & & Grade & Category & & \\
1 & 24 & V & High & High & High \\
2 & 28 & VI & Very High & High & Very High \\
3 & 25 & V & High & High & High \\
4 & 25 & V & High & Moderate & High \\
5 & 19 & IV & Moderate & Moderate & Moderate \\
6 & 26 & VI & Very High & High & Very High \\
7 & 28 & VI & Very High & High & Very High \\
8 & 12 & III & Low & Low & Low \\
9 & 17 & IV & Moderate & Moderate & Moderate \\
10 & 17 & IV & Moderate & Moderate & Moderate \\
11 & 15 & III & Low & Low & Low \\
\hline
\end{tabular}




\section{Discussion}

The results from the current study indicate that unstable slopes exist along the studied parts of the road representing potential areas for landslides. In order to facilitate the discussion, the studied parts of the road cut were divided into three main sections (Table 2 and Fig. 1). Sections A - B and B - C, are dangerous with many mass movements phenomena, whereas Section $\mathrm{C}-\mathrm{D}$ suffers from minor instability problems after serious efforts were made to stabilize these slopes.
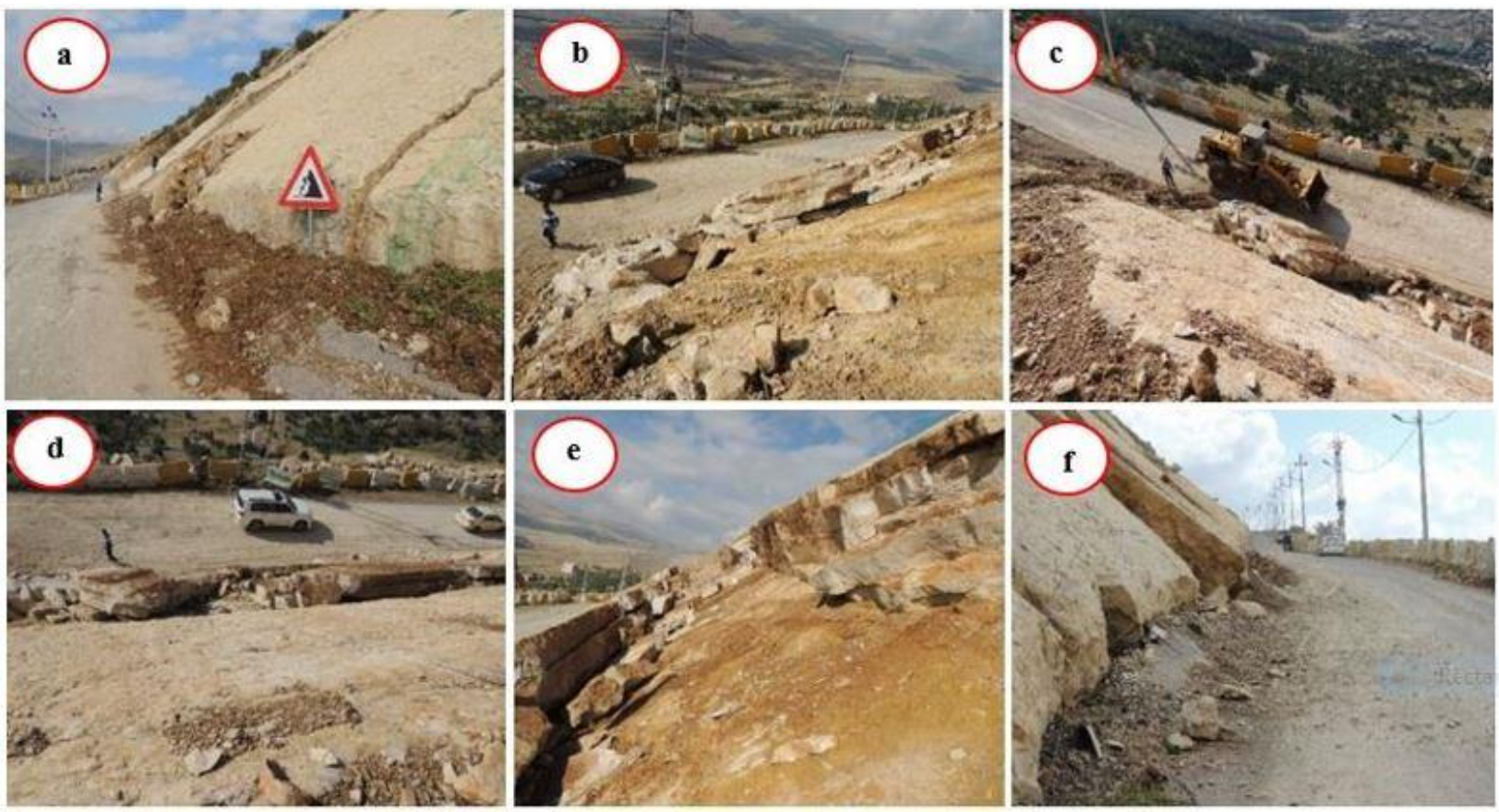

Fig. 3. Landslide of 11 November 2015 at Haibat Sultan Mountain. 3a) Traffic sign for rock falls indicating continuous landsliding, 3b) Large slid blocks, 3c) Top view of the landslide, 3d) Top view of the landslide, note the damaged road fence; in the back ground, 3e) The shear plane of sliding, 3f) Toe of the landslide, note the road had functioned as a retaining wall to stop the sliding of the rock blocks.

The differences in the instability problems between the mentioned three sections are attributed to: 1) The slopes in the first sector are dip slopes, whereas in the second sector are anti-dip slopes, 2) The exposed formations in the first sector are the Fatha and Pila Spi formations (Fig. 2). The former consists of thick red claystone with very thin limestone and gypsum. The latter consists of dolomite, dolomitic limestone, well bedded and hard to very hard; however, the former covers only the first $200 \mathrm{~m}$; whereas the latter covers the remaining portion of the sector, which is about $1700 \mathrm{~m}$. In the second sector, the exposed formation is Gercus (Fig. 2). The formation consists of thinly, well bedded, reddish brown claystone with thin horizons of limestone. The formation covers the majority of this part.

\section{1. Sections $A-B$ and $B-C$ of the Road}

Sections A - B and B - C include studied stations No. $1-7$ (Fig. 1). The main reasons for the presence of landslides and potential areas for sliding are: 1) The majority of the road cuts are parallel to the bedding planes of the Pila Spi Formation, where the bedding planes daylight in the slope faces (Figs. 3 and 4), 2) Locally, claystone and/ or residual clayey soil form potential areas for sliding (Studied stations No. 1 and 2) (Fig. 5), especially when oversaturated by rain water, which will increase the pore water pressure. This will decrease the internal friction and cause sliding (Terzaghi, 1943, and Terzaghi et al. 1996), 3) The rocks of the Pila Spi formation, locally include claystone layers (Fig. 6a) that can 
produce lubricated sliding surfaces, and karst cavities (Fig. 6b), which accelerates water penetration in the slope causing the failure.
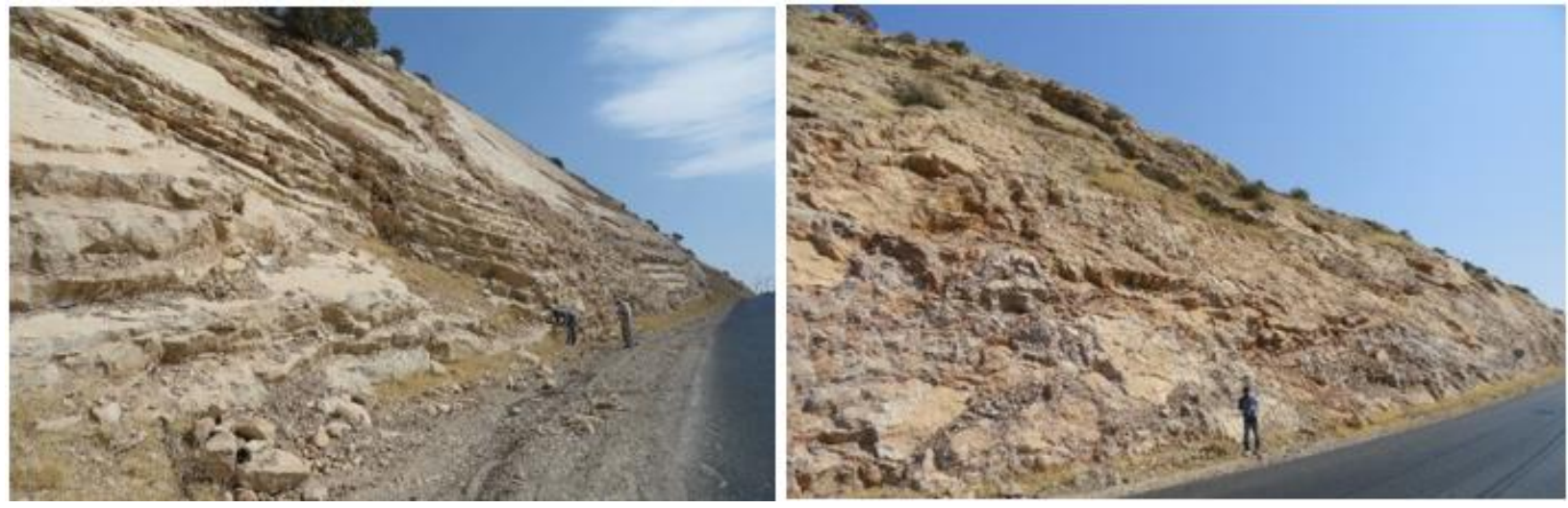

Fig. 4. Road Cuts with well bedded, carbonate rocks of the Pila Spi Formation where bedding planes daylight in the slope face (Station No. 7)
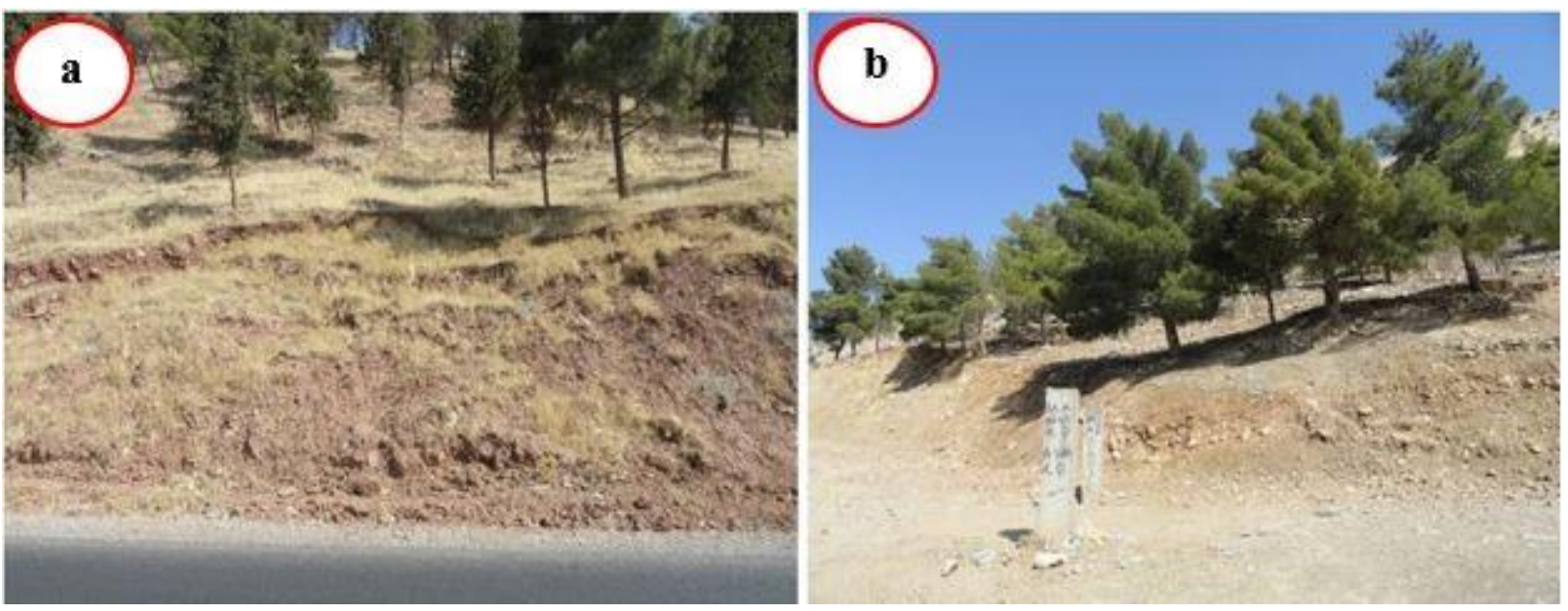

Fig. 5. Two unstable slopes in residual soils. 5a) Studied station No. 1, note the recent failure with the developed cliff in the crown area. 5b) Studied station No. 2, note the inclined trees
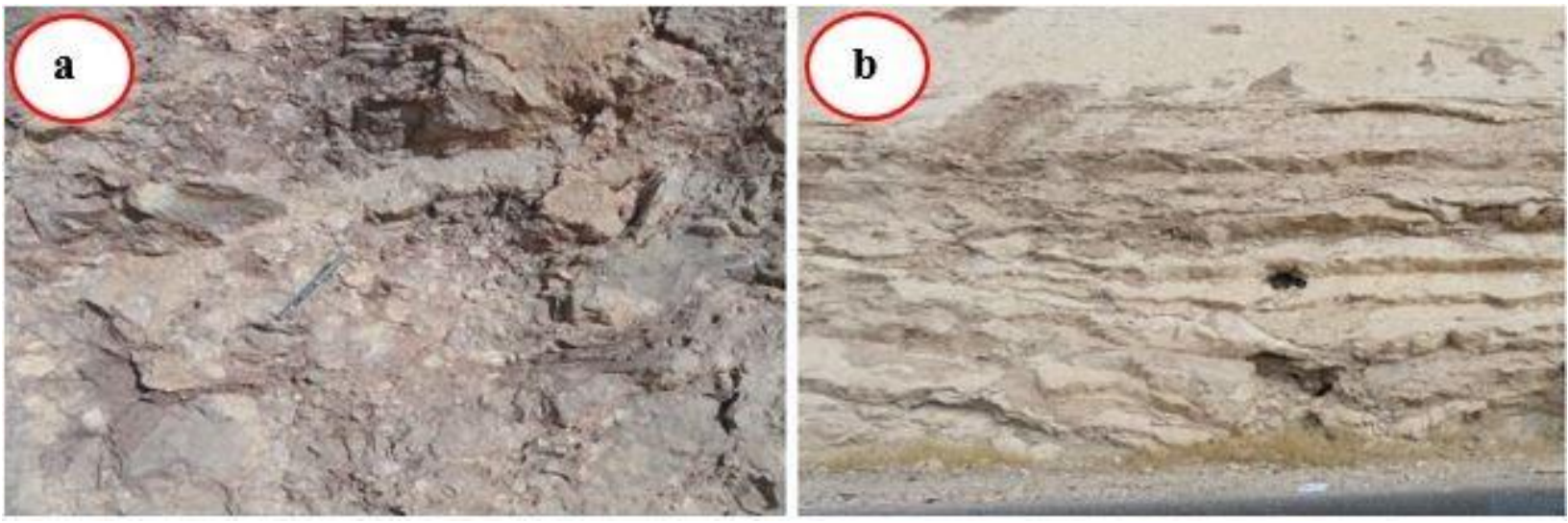

Fig. 6. The Pila Spi Formation, 6.a) Reddish brown claystone, it acts as a lubricant surface for sliding after being oversaturated, 6.b) Karst cavities, which accelerate water penetration 


\subsection{Section C - D of the Road}

Section C - D includes studied stations No. 8 - 11 (Fig. 1). In this section, no sliding can occur along the main road cut. However, when the face of any road cut runs almost perpendicular to the slope of the main road cut; then sliding may occur (Fig. 7a). The main mass wasting, which occurs along the road is in the form of rock disintegration (Fig. 7a and 7b). This is attributed to: 1) The claystone beds within the Gercus Formation are thinly bedded and intensely jointed (Fig. 7a); therefore, these areas are prone to disintegrate; even though the road runs along slopes, which are opposite to the dip direction, 2) The directions of the road cuts and their slope angles intersect with the attitudes of the bedding and joint planes and form unstable slopes, and/ or prone areas for wedge failure (Fig.7a), and 3) The anti-dip slope is capped by the carbonate rocks of the Pila Spi Formation forming hanging cliffs (Fig. 7b) because of the weathering of the soft rocks of the Gercus Formation, thus forming unstable slopes, which may exhibit toppling, sliding and occasionally rock fall. It should be noted that the local transportation agency has modified the road cut with a $30 \mathrm{~m}$ offset from the toe of the slope to the road. This will decrease the likelihood of a wedge failure which could produce a large landslide along the road cut.
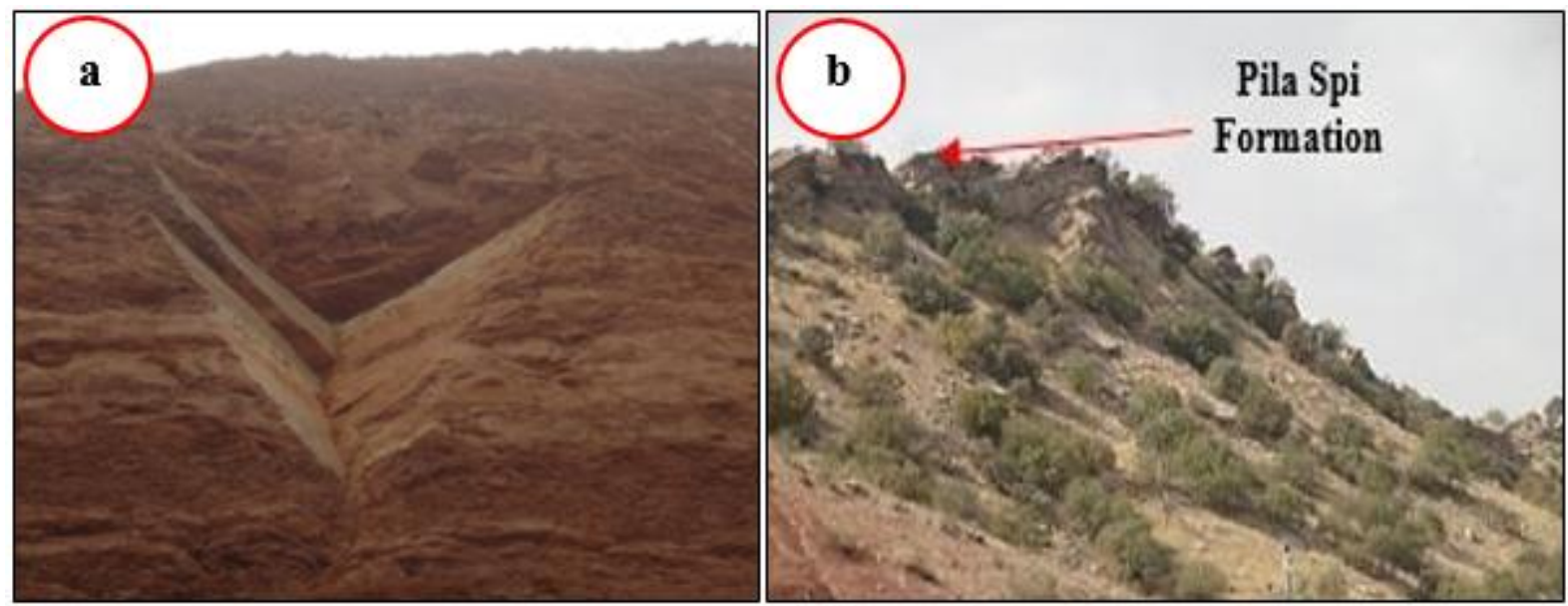

Fig. 7a. The Gercus Formation, well bedded and intensely jointed claystone beds and wedge sliding (Studied station No. 10), Fig. 7b: Hanging cliffs formed by the carbonates of the Pila Spi Formation, overlying soft rocks of the Gercus Formation; forming prone areas for sliding, toppling and rock fall

\section{Conclusions}

Sections A - B and B - C suffer from landslides of large rock masses of the Pila Spi Formation, and soil failure within the residual soil and/ or the highly weathered claystone beds of the Fatha Formation. Section C - D suffers from mass wasting with occasional wedge failure due to the presence of soft, well bedded and intensely jointed claystone beds of the Gercus Formation; therefore, the mass wasting products are in the form of small rock fragments (chips). The minimum scored L.P. I. value was 12 at station 8 within section $\mathrm{B}-\mathrm{C}$, and has Low Failure Possibility, whereas the maximum recorded L.P.I. value was 28 at stations No. 2 within section A - B, and has very High Failure Possibility, besides station No.7 within section B $-C$ that witnesses a large landslide that had occurred on $30^{\text {th }}$ April 2019 after a heavy rain shower. Therefore, very high scored L.P.I. values are excellent indication for instable slopes. The sliding masses in sections $\mathrm{A}-\mathrm{B}$ and $\mathrm{B}-\mathrm{C}$ are large; up to more than one cubic meter, whereas in section $\mathrm{C}-\mathrm{D}$, the mass wasting is in the form of very small pieces. This is attributed to the exposed rocks of the Pila Spi Formation along section B - C, whereas in section C - D, the Gercus Formation is exposed. 


\section{Recommendations}

The scored L.P.I. values based on Bejerman (1994) method can be used to indicate slope stability problems; therefore, we highly recommend using the method in evaluation of road cuts. Accordingly, the following remedial measures are recommended to keep the road cuts as safe as possible:

- Excavation of: 1) channels that are lined with insulating material in the upper part of the unstable slopes to decrease water infiltration into the ground material, in the First Sector, 2) channels that are lined with insulating material at the base of the slopes facing the paved road to redirect rainwater away from the road and reduce the percolation of the water into the rocks and soil, 3) construction of rock fall barriers along the slopes which are covered by the soft rocks of the Gercus Formation in the anti-dip slope side (Section C - D).

- Installing of: 1) support elements such as rock bolts in the limestone beds of the Pila Spi Formation, which form daylighting slopes, in Section B - C, 2) suitable steel dowels and concrete buttresses at selected locations in the First Sector, 3) digging horizontal drains in the slope of Section $(\mathrm{A}-\mathrm{B})$ to reduce pore water pressure at specific locations, 4) erection of retaining walls between the slope and the road along the Second Sector. Spraying shotcrete along the slopes which are covered with soft rocks at specific locations.

- Removing all rock dumped on the dip-slope side of the road, opposite the toe of the slope.

- Maintaining offsets or constructing additional offsets between the road and the toe of the slope in Section $\mathrm{C}-\mathrm{D}$, at needed locations.

\section{Acknowledgements}

Providing logistic support for performing of the field work, which was supplied by the University of Kurdistan Hewler, Erbil, IKR during the field work is highly appreciated by all authors. The authors are very grateful to the Editor in Chief Prof. Dr. Salih M. Awadh, the Secretary of Journal Mr. Samir R. Hijab. and the Technical Editors for their great efforts and valuable comments.

\section{References}

Admassu, Y., 2014. Dip Analyst 2.0. Stability Analysis Software for Rock Slopes.

Al-Saadi, S. N., Yousif, L.D., 2013. Landslide hazard of rock slopes around Shaqlawa City, Kurdistan Region, NE Iraq, with modified classification of hazards on roads and proposing remedial measurements. Journal of Zankoy Sulaimani, 15 (3), 3.

Bejerman, N.J., 1994. Landslide Possibility Index System. Proceedings $7^{\text {th }}$ International Congress of IAEG, Balkema, Rotterdam, 3, 1303 - 1306.

Bejerman, N.J., 1998. Evaluation of landslide susceptibility along a sector of state road E-55, Cordoba Argentina. Proceedings, $8^{\text {th }}$ International Congress of IAEG, Vancouver, Canada, Balkema, Rotterdam, 2, 1175- 1178.

Bieniawski, Z. T., 1989. Engineering Rock Mass Classifications, John Wiley and Sons. 272 pp.

Fouad, S. F., 2015. Tectonic Map of Iraq, scale 1:1000000, $3^{\text {rd }}$ Edition. Iraq Geological Survey Publications, Baghdad, Iraq.

Hack, R., Price, D., 1997. Quantification of Weathering. Conference: Engineering Geology and the Environment; Proceedings of an International Symposium of the IAEG. At: Athens, Greece.

Hamasour, G. A., 1991. Engineering-Geological Study of Rock Slope Stability in Haibat Sultan area, NE Iraq. Unpub. M.Sc. thesis, University of Salahaddin, Erbil, Iraq. 153 pp.

Hocking, G., 1976. A method for distinguishing between single and double plane sliding of tetrahedral wedges. International Journal of Rock Mechanics and Mining Sciences, 13(7), 225-226.

Hoek, E., Bray, J.W., 1981. Rock Slope Engineering". Revised 3rd Edition, The Institution of Mining and Metallurgy, London, 341-351. 
Hungr, O., Leroueil, S., Picarelli, L., 2003. The Varnes classification of landslide types, an update. Landslides, 11, 167-194.

Jassim, H. M., Saad, S. A., Ghafour, B. D., 2013. Slope stability assessment along the Haibat Sultan main road, Koya, Kurdistan. Proceedings of First International Symposium on Urban Development, Koya.

Jassim, H. M., Rasheed, Z. N., Ghafour, B. D., Ahmed, F. R., 2014. On the Landslide of Daigala Slope-Kurdistan-Iraq. IJETT, 12 (10), 503-509.

Markland, J. T., 1972. A useful technique for estimating the stability of rock slopes when the rigid wedge sliding type of failure is expected. Imperial College Rock Mechanics Research Report, 19, 10 pp.

Matula, M., 1981. Rock and soil description and classification for engineering geological mapping report by the IAEG Commission on Engineering Geological Mapping. Bulletin of the International Association of Engineering Geology 24, 235 - 274.

Mohammed, F.O., Jalal, A., Hawre, S., 2020. Landslide susceptibility assessment along Biyara-Tawela Road, Kurdistan region, NE-Iraq. Zankoy, 22 (1), 1-38.

Sidiq, S. A., Muhmed, A. S., Haris, G. K., Hamma, D. M., Abdullah, M. M., Bibani. H. H., Muhealldin, H. K., Mustafa, H. A., Sissakian, V. K., Al-Ansari, N., 2016. Mechanism of Haibat Sultan Mountain Landslide in Koya, North Iraq. Engineering, 8, 535-544.

Sissakian, V. K., Al-Jibouri, B.M., 2014. Stratigraphy: In Geology of the High Folded Zone. Iraqi Bulletin of Geology and Mining, 6, 73 - 161 .

Sissakian, V.K., Abdul Ahad, A., Hamid, A.T., 2011. Geological Hazards in Iraq, Classification and geographical distribution. Iraqi Bulletin of Geology and Mining, 7 (1), 1-28.

Sissakian, V.K, Omar, H.O. and Mustafa, Z.T., 2018. Assessment of Unstable Slope in Korre Village, SW of Shaqlawa Town, the Kurdistan Region. UKH Journal of Science and Engineering, 2 (2) 14 - 22.

Sissakian, V. K., Al-Ansari, N., Abdulahad, A.D., 2020. Indicating the Possibility of Activation of Large and Old Landslides and Risk Estimation Using Remote Sensing and Field Data, Examples from the Iraqi Kurdistan Region. Geotectonics, 2020, 54 (2), 240-255.

Terzaghi, K., 1934. Large Retaining Wall Tests. Engineering News Record Feb. 1, March 8, April 19.

Terzaghi, K,, Peck, R.B., Mesri, Gh., 1996. Soil Mechanics in Engineering Practice. John Wiley and Sons.

Yousif, L., Shakir, M., 2015. Assessment of rockfall hazards on Mirawa - Mawaran Main Road, Kurdistan Region, N Iraq. Iraqi Bulletin of Geology and Mining, 11 (3) 107-116.

Watts, C.F., Gilliam, D.R., Hrovatic, M.D., Hong, H., 2003. User's Manual - Rockpack III for Windows, C.F.Watts and Associates, Radford, VA, USA, 33 pp. 